\title{
The influence of the culture of society on the effectiveness of anti-corruption measures of the state
}

\author{
Larisa Aleksandrovna Popova ${ }^{11}$, and Petr Leonidovich Surikhin ${ }^{2}$ \\ ${ }^{1}$ Surgut State University, Department of Criminal Law and Procedure, Surgut, Russia \\ ${ }^{2}$ Siberian Federal University, Department of Criminal Law, Krasnoyarsk, Russia
}

\begin{abstract}
The study aims to analyze the impact of different types of national cultures on the effectiveness of anti-corruption measures implemented by the states, expressed in the change in the Corruption Perceptions Index for the period from 2016 to 2020. The methodological basis was such scientific methods as dialectical, logical, prognostic, and systems analysis. The methods of statistics were also used to achieve the research objectives. The study attempts to analyze the relationship between the cultural area of the country and its place in the international rating, compiled annually based on the results of the research conducted by the international organization Transparency International. The result of the study was the conclusion regarding the predominance of the countries of the Western European cultural area in the leaders of the rating as the countries with the lowest corruption perceptions index, the countries of the African cultural area as the countries predominating in the composition of the states with the highest corruption perceptions index and proportional representation of the countries of the Eastern European, South Asian and Latin American cultural area in the median values of the rating. The novelty of the work lies in the division of the countries existing in the modern world into eight cultural areas based on the value attitudes, traditions, and beliefs formed in them, which enabled to analyze the representation of countries of a particular area in a certain group of ratings - the countries with a low corruption perceptions index, the countries with a high corruption perceptions index and the countries, in the corresponding analyzed period, occupying the median position in the rating.

Keywords: national cultures, anti-corruption, corruption perceptions index, cultural areas
\end{abstract}

\section{Introduction}

Anti-corruption strategies in different countries may differ from each other, but they always have only one goal as the main one - to minimize the spread of this negative phenomenon,

${ }^{1}$ Corresponding author: popova la@surgu.ru 
which brings enormous harm to the state and the society. Despite active anti-corruption efforts made in most countries of the modern world, their results are not always the same.

The history of the fight against corruption is quite long, and the geography is vast. The considered phenomenon takes place to one degree or another in any country in the world. However, the existing methods of measuring corruption clearly show that this phenomenon is not equally widespread in all countries. Culture as a social phenomenon is studied by a whole range of sciences, starting from philosophy to the research by psychologists and anthropologists. The attention of legal scholars is often paid to such a phenomenon as legal culture [1]. The relationship between law and culture has become the subject of a monographic study by such well-known Russian scientists as Nersesyants, Muromtsev, Maltsev et al. [2]. Regarding the direct study of the influence and correlations of culture and corruption, unfortunately, this aspect is currently insufficiently studied by the Russian science. First of all, this is due to the complexity of analyzing and measuring these phenomena. Until now, in the world science there are no unambiguous and generally accepted criteria for measuring cultures. The most significant works in the field of measuring culture and analyzing its impact on the society can be called the works by Hofstede [3], Schwartz [4, 5], Inglehart [6, 7], Triandis [8], Bond, and Leung [9]. The problems of the relationship between the cultural values of society and corruption were studied by Klitgaard [10], and Reisman [11]. In Russian science, the influence of culture on the level of corruption was studied by Koptseva [12], Nestik [13], etc.

The research conducted since 1996 by the international organization Transparency International, on the basis of which the Corruption Perceptions Index (hereinafter - CPI) is calculated annually, provides a basis, though not indisputable, but accepted by the international community, for assessing the prevalence and impact of corruption on society in a particular state. Analyzing the CPI of individual countries and its annual change, comparing it with the peculiarities of the culture of these states, a conclusion can be drawn about the relationship between the cultural structure and the level of corruption. The scientific substantiation of such a correlation can become the basis for adjusting the system of anti-corruption measures of the state in order to increase their effectiveness.

\section{$2 \quad$ Methods}

The methods of statistics were used to achieve the objectives of the research. A statistical sample of indicators was taken that allows to conduct a comparative analysis of the spread of corruption relations in individual states, and an analysis of the relationship between the success of anti-corruption measures and the peculiarities of the cultural structure of the state was performed. The method of systems analysis enabled to compare the data and interpret the obtained results.

In the study, the authors used publicly available data from the international organization Transparency International.

To assess the state of society in terms of the spread of corruption, it is considered possible to use the CPI and the rating of the countries of the world, formed on its basis, annually published by the international organization Transparency International (hereinafter, the data from [14] are used), which give a fairly objective idea of the issue of interest to the authors. Due to the fact that in the period from 2015 to 2020, approximately the same number of countries participated in the Transparency International study (180 countries in the 2017-2020 studies, 176 countries in 2016 and 168 in 2015), the authors took this five-year period for the analysis. As a sample, the authors determined an equal number for the analysis - ten countries - from among the leaders of the rating, from among 
outsiders and from among countries in the middle of the distributed range. In total, there are 30 countries, based on the specified rating and their place in it for each year of the examined period.

\section{$3 \quad$ Results}

The conducted study of the relevance to the cultural area of a sample of 30 countries, ranked depending on the CPI value, as occupying leading positions (the first ten countries in the rating), outsiders in the rating (the last 10 countries) and occupying the median value of the rating (countries in the ninth ten positions in the rating), according to the data for the period from 2016 to 2020, showed a significant predominance of the countries of the Western European cultural area in the top ten countries. It is noteworthy that throughout the examined period, the list of the top ten countries remained practically unchanged. Among the leading countries in the rating, the attention is drawn to only one country which traditions belong to a different cultural area - Singapore, representing the Far East Asian cultural area.

Table 1. Distribution of the sample of countries, ranked by the Corruption Perceptions Index (CPI), by cultural area (2016-2020).

\begin{tabular}{|l|l|l|l|l|l|l|l|l|l|l|l|l|l|l|l|}
\hline \multirow{2}{*}{$\begin{array}{l}\text { Cultural } \\
\text { area }\end{array}$} & \multicolumn{3}{|c|}{ 2016 } & \multicolumn{3}{|c|}{ 2017 } & \multicolumn{3}{c|}{ 2018 } & \multicolumn{3}{c|}{ 2019 } & \multicolumn{3}{c|}{ 2020 } \\
\cline { 2 - 13 } & L & O & M & L & O & M & L & O & M & L & O & M & L & O & M \\
\hline $\begin{array}{l}\text { Western } \\
\text { European }\end{array}$ & 7 & & & 7 & & & 7 & & & 8 & & & 8 & & \\
\hline $\begin{array}{l}\text { English-spea } \\
\text { king }\end{array}$ & 2 & & & 2 & & & 2 & & & 1 & & & 1 & & \\
\hline $\begin{array}{l}\text { Far East } \\
\text { Asian }\end{array}$ & 1 & 1 & 1 & 1 & 1 & & 1 & 1 & 1 & 1 & 1 & & 1 & 1 & \\
\hline $\begin{array}{l}\text { Eastern } \\
\text { European }\end{array}$ & & & 1 & & & 3 & & & 4 & & & 2 & & & 2 \\
\hline $\begin{array}{l}\text { Latin } \\
\text { American }\end{array}$ & & 1 & 3 & & & 2 & & & & & 1 & 1 & & 2 & 4 \\
\hline South Asian & & & 1 & & & 1 & & & 2 & & & 4 & & & 1 \\
\hline African & & 5 & 3 & & 6 & 3 & & 6 & 3 & & 5 & 3 & & 4 & 2 \\
\hline $\begin{array}{l}\text { Arabic } \\
\text { Islamic }\end{array}$ & & 3 & 1 & & 3 & 1 & & 3 & & & 3 & & & 3 & 1 \\
\hline Total & 1 & 1 & 1 & 1 & 1 & 1 & 1 & 1 & 1 & 1 & 1 & 1 & 1 & 1 & 1 \\
& 0 & 0 & 0 & 0 & 0 & 0 & 0 & 0 & 0 & 0 & 0 & 0 & 0 & 0 & 0 \\
\hline
\end{tabular}

Conventional signs: $\mathrm{L}$ - countries in the top ten of the CPI rating, $\mathrm{O}$ - countries in the last ten of the $\mathrm{CPI}$ rating, $\mathrm{M}$ - countries with a median value in the $\mathrm{CPI}$ rating

In the group of the outsider countries of the rating, the tendency for the predominance of countries-representatives of the African cultural area is clearly expressed. A country that is not a representative of this area, but is regularly present in the rating of countries with a high CPI is Syria. Obviously, in this case, this is a natural consequence of the socio-political processes that have taken place in this state over the recent time.

The cultural areas of the countries represented in the middle of the CPI rating are distributed relatively evenly over the years. Equally, during the study period, the countries of the Eastern European, Latin American and South Asian areas are represented.

Attention is drawn to the fact that the list of leading countries with a low CPI, as well as outsider countries with the highest index, has practically remained unchanged over the past five years. As for the countries occupying the median position in the rating, their list 
changed every year, but one should pay attention to the fact that these countries belong to the above-mentioned cultural areas, the list of which, in turn, remained practically unchanged.

\section{Discussion}

In the world science, there are a number of recognized research approaches to measuring cultures, each of which is of undoubted value in the context of the tasks it faces, which, as a rule, have one main goal - to explain the influence of culture on the level of development of society, as well as its features of economic and social development.

Based on the hypothesis of the research, the authors did not set such goals. The authors are primarily interested in analyzing the existence of a connection between groups of states with similar cultural characteristics, and the effectiveness of anti-corruption measures taken by them. For the distribution of the states into groups, taking into account their cultural characteristics, it is considered most appropriate to use the so-called cultural areas, the method of determining which was proposed by Lebedeva and Tarko [15]. In accordance with the specified method, which was based on the axes of measurement of cultures based on the concepts of Inglehart and Schwartz, the countries were distributed over the following cultural areas.

1. Western European cultural area. The population of the countries included in it is characterized by the development of post-materialistic values: autonomy, self-expression, equality, harmony, tolerance, and political participation. In addition, a high level of democracy and gender equality are noted as cultural characteristics. This includes countries such as Sweden, Germany, Norway, Finland, and the Netherlands.

2. English-speaking cultural area. The countries that are close to the Western European countries, but differ from them in some basic values - they are less open to migration and are guided primarily by economic rather than humanitarian considerations. This group includes countries such as the USA, New Zealand, Great Britain, and Ireland.

3. Far East Asian cultural area. This cultural group is characterized by the following: a high level of social and economic capital, a low level of tolerance towards others, and a low level of individual autonomy. Gender equality is discouraged. These are countries such as Japan, China, Singapore, and South Korea.

4. Eastern European cultural area. It is represented by a fairly large set of countries that have significant differences in a number of parameters. Nevertheless, the main common cultural features are the average (for post-Soviet countries - low) level of social capital, low level of tolerance, insufficient attention to environmental issues, and patriarchy. This group includes such countries as the Czech Republic, Croatia, Estonia, Latvia, and Georgia.

5. Latin American cultural area. These countries are characterized by traditional and hierarchical values, and a relatively low level of economic development. These are the countries of Latin America, such as, for example, Argentina, Chile, Peru, and Venezuela.

6. South Asian cultural area. High value of hierarchy, material things, group survival, and religion are noted as characteristic features. This group includes countries such as India and the Philippines.

7. African cultural area. Expressed values of hierarchy, traditionalism and survival. This group includes the countries of the African continent.

From the point of view of the peculiarities of the community of cultural values, it is considered necessary to highlight one more cultural area - the Arabic Islamic one. The significant role of religion, patriarchy, and gender inequality are the main characteristic features of this area. 
The study showed that cultural characteristics largely determine the effectiveness of anti-corruption measures implemented in modern states. The countries belonging to the Western European cultural area show a consistently low corruption perceptions index, in contrast to the countries of the African cultural tradition. Obviously, the intensity of anti-corruption measures implemented by the states should also differ in these countries. The states that are in the middle of the rating, as it was already mentioned, are constantly changing, but the cultural areas they represent are stable, which indicates the dynamism of the processes taking place in the countries on the one hand, directly reflected in the place of this or that country in the rating, but, at the same time, the presentation of the same cultural area, but already by other countries, actually confirms the priority of cultural values prevailing in the corresponding group of states.

\section{Conclusion}

UNESCO defines culture as a complex of special spiritual, material, intellectual, and emotional characteristics of a society or a social group that encompasses not only art and literature, but also lifestyles, ways of living together, value systems, traditions and beliefs [16]. The acceptance as social values of respect for another person and his or her rights, the reduction of the distance between the authorities and the society, a change in the priority of material enrichment and acceptance as basic, spiritual values should become part of the culture of any modern society. Failure to accept these values, regardless of the reasons, largely determines the spread of corruption relations in individual states.

Forming a rejection of corruption as an integral value of the society is an indispensable condition for the success of anti-corruption measures implemented by any state, which, in turn, is the most important condition for stable development in the modern world.

\section{References}

1. L.A. Petruchak, Pravovaya kul'tura sovremennogo rossiiskogo obshchestva: monografiya [Legal culture of modern Russian society: monograph] (Pero, Moscow, 2012)

2. V.S. Nersesyants, G. I. Muromtsev, G. I. Maltsev et al., Pravo i kul'tura: monografiya [Law and Culture: monograph] (Publishing house of Peoples' Friendship University of Russia, Moscow, 2002). Accessed on: July 4, 2021. [Online]. Available: http://www.centrlaw.ru/publikacii/page35/page37/index.html

3. G. Hofstede, Culture's consequences: International differences in work-related values (Sage, Beverly Hills, 1980)

4. S.H. Schwartz, Universals in the content and structure of values: Theory and empirical tests in 20 countries, in M. Zanna (ed.), Advances in experimental social psychology, 25, 1-65 (Academic Press, New York, 1992) https://doi.org/10.1016/S0065-2601(08)60281-6

5. S.H. Schwartz, Beyond individualism/collectivism: New cultural dimensions of values, in U. Kim, H.C. Triandis, C. Kagitcibasi, S.-C. Choi, G. Yoon (eds.), Individualism and collectivism: Theory, method, and applications, 85-119 (Sage, Thousand Oaks, CA, 1994)

6. R. Inglehart, Modernization and Postmodernization. Cultural, Economic and Political Change in 43 Societies (Princeton Univercity Press, Princeton, 1997)

7. R. Inglehart, W. Baker, American Sociological Review, 65, 19-51 (2000) 
8. H.C. Triandis, Culture and Social Behavior (McGraw-Hill, New York, 1994)

9. M.H. Bond, K. Leung, A. Au, K.K. Tong, S. Reimel de Carrasquel, F. Murakami, et al., Journal of Cross-Cultural Psychology, 35, 548-570 (2004)

10. R. Klitgaard, Adjusting to reality: Beyond "state versus market" in economic development (ICS Press, San Francisco, 1991)

11. W. Reisman, Folded Lies (The Free Press, New York, 1979)

12. N.P. Koptseva, Human and Culture, 3, 23-50 (2014). https://doi.org/10.7256/2306-1618.2014.3.12905

13. T.A. Nestik, Corruption and culture, Investigator, 5, 47-52 (2008)

14. Transperensi interneshnl Rossiya [Transparency International Russia]. Accessed on: July 4, 2021. [Online]. Available: https://transparency.org.ru/

15. N.M. Lebedeva, A.N. Tarko, Kultura kak faktor obshchestvennogo progressa [Culture as a factor of social progress], 343-346 (ZAO "Yustitsinform", Moscow, 2009)

16. UNESCO Universal Declaration on cultural diversity (UNESCO, Paris, 2021) 